\title{
Reseach Note
}

\section{WEED CONTROL IN PASTURE ESTABLISHMENT'}

Weed control is an important practice for the local farmer in the establishment of pastures. According to Almodóvar (1989)", pastures should be maintained weed free from their initial establishment. Chemical weeding during this stage is most effective and economical for forage grass production. The information on the use of diuron and 2,4-D combinations on new Cynodon accessions is limited. Burton (1993): suggested that $2,4-\mathrm{D}$ is an excellent preemergence herbicide for both grass and broadleaf weeds if applied the same day the grass is planted. However, this herbicide is mainly for broadleaf weed control. The objective of this study was to evaluate 2,4-D (preemergence and postemergence) and diuron, alone and in a tank mixture in two new pasture establishments.

The experiment was established on a Corozal clay soil series at the Agricultural Experiment Station at Corozal. The soil pH was 4.81 with an organic matter content of $2.32 \%$. Each experimental plot was $2.75 \mathrm{~m}$ wide by $2.75 \mathrm{~m}$ long with three rows within a plot. Cynodon nlemfuensis (stargrass) and Cynodon dactylon cv Tilton 85 were used. Both pasture species in the form of mature stolons were individually planted in the soil on 10 February 1994. Treatments were diuron at 1.68 and 3.36 $\mathrm{kg}$ ai/ha and 2,4-D at $2.24 \mathrm{~kg}$ ai/ha. Herbicide treatments were applied preemergence (PRE), postemergence (POE), alone and in tank mixture (Table 1). Weedfree and weedy plots were included as checks. Herbicide treatments were applied with a $\mathrm{CO}_{2}$ backpack sprayer that delivered 187 liters/ha. A $2 \times 9$ factorial arrangement in a randomized complete block design with nine treatments and three replicates was used. Preemergence treatments were applied a day after planting. Postemergence treatments were applied three weeks after weed emergence. Visual estimates of weed control were made 10 weeks after planting (WAP). The crops were harvested five months after planting. Protein content of the pastures was also determined. Means were separated by Least Significant Differences (LSD) at $\mathrm{P} \leq 0.05$.

No significant interactions occurred for data involving two Cynodon spp. pastures; therefore, data were combined. There were no significant differences in yield and protein percentage among the herbicide treatments and the checks (Table 1). Junglerice [Echinochloa colona (L.) Link], large crabgrass [Digitaria sanguinalis (L.) Scop.] and signalgrass [Brachiaria platyphylla (Griseb) Nash], were the most common grasses. The most abundant broadleaves in the pasture study were Gale of the wind (Philantus niruri L.), spreading dayflower (Commelina diffusa), "lechecillo" [Chamaesyce hirta (L.) Millsp.], "boton blanco" [Borreria verticillata (L.) G. F. W. Meyer], and Florida beggarweed (Desmodium tortuosum Sw. DC). Diuron at $1.68+2,4-\mathrm{D}$ at $2.24 \mathrm{~kg}$ ailha (PRE), and 2,4-D at $2.24 \mathrm{~kg}$ ai/ha

'Manuscript submitted to Editorial Board 21 February 1995.

${ }^{2}$ Almodóvar, L., 1989. Control de malezas en pastos cultivados y pastizales. Memorias: $3^{\text {rra }}$ Conferencia sobre Pastos y Ganadería. Servicio de Extensión Agricola, Recinto Universitario de Mayagüez, 2-3 marzo 1989. pags. 123-130.

BBurton, G. W., 1993. Hybrid bermudagrass for hay and pasture. Fact sheet. Coastal Plain Experiment Station, Tifton, Georgia. 
TABLE 1,-Weed control, yield and pasture protein percentage."

\begin{tabular}{|c|c|c|c|c|c|}
\hline Treatment & Rate & $\begin{array}{c}\text { Weed } \\
\text { control }^{2}\end{array}$ & $\begin{array}{c}\text { Weed } \\
\text { (dry weight) }\end{array}$ & $\begin{array}{l}\text { Pasture yield } \\
\text { (fresh weight) }\end{array}$ & Protein \\
\hline & $\mathrm{kgai} / \mathrm{ha}$ & $\%$ & \multicolumn{2}{|c|}{$\mathrm{kg} / 81 \mathrm{~m}^{2}$} & $\%$ \\
\hline Diuron & 1.68 $\mathrm{PRE}^{3}$ & 37 & 3.58 & 200 & 6.9 \\
\hline Diuron & 3.36 PRE & 27 & 4.52 & 306 & 7.7 \\
\hline Diuron & $1.68+2.242 .4-D$ PRE & 44 & 2.35 & 290 & 6.9 \\
\hline Diuron & $\begin{array}{l}1.68(\mathrm{PRE})+2.242,4-D \\
(\mathrm{POE})\end{array}$ & 77 & 2.22 & 359 & 8.1 \\
\hline Diuron & $3.6+2.242,4-D$ (PRE) & 57 & 2.35 & 257 & 7.9 \\
\hline $2,4-\mathrm{D}$ & 2.24 (PRE) & 49 & 2.65 & 312 & 7.8 \\
\hline $2,4-\mathrm{D}$ & 2.24 (POE) & 88 & 2.33 & 164 & 5.9 \\
\hline $\begin{array}{l}\text { Weed-free } \\
\text { check }\end{array}$ & - & 100 & 0.0 & 277 & 7.7 \\
\hline Weedy check & - & 0 & 3.52 & 129 & 7.6 \\
\hline $\operatorname{LSD}(0.05)$ & & 26 & 2.31 & N.S. & N.S. \\
\hline
\end{tabular}

'Data combined for both pastures (Stargrass and Tifton-85).

${ }^{2}$ Weed control index was based on: $0=$ no effect (no weed control), $100=$ complete effect (complete weed control).

${ }^{3} \mathrm{Abbreviations}: \mathrm{PRE}=$ preemergence, $\mathrm{POE}=$ postemergence application.

(POE) gave 77 to $88 \%$ control of weeds, respectively (Table 1). Dry weights of weeds in these treatments were 2.22 and $2.33 \mathrm{~kg} f$ $81 \mathrm{~m}^{2}$, respecively. However, there were no significant differences in yield among these two treatments and the weedycheck. Other 2,4-D and diuron treatments gave poor weed control $(27-57 \%)$. Neither of the herbicide treatments evaluated was phytotoxic to either pasture. Burton (1993)" suggested that 2,4-D is an excellent preemergence herbicide for both grass and broadleaf weeds. However, in this study the preemergence application of this herbicide alone did not effectively control weeds.

Maria de L. Lugo

Assistant Weed Scientist

Rafael Ramos

Assistant Researcher

Lii C. Liu

Plant Physiologist 